\title{
Production and characterisation of mouse monoclonal antibodies reacting with the lipopolysaccharide core region of gram-negative bacilli
}

\author{
B. J. APPELMELK, A. M. J. J. VERWEIJ-VAN VUGHT, J. J. MAASKANT, W. F. SCHOUTEN, \\ A. J.R. DE JONGE*, L. G. THIJSt and D. M. MACLAREN
}

Research Group for Commensal Infections, "Department of Pharmacology and TMedical Intensive Care Unit, School of Medicine, Vrije Universiteit, v.d. Boechorststraat 7, P.O.B. 7161, 1007 MC Amsterdam, The Netherlands

\begin{abstract}
Summary. Monoclonal antibodies to the lipopolysaccharide (LPS) core region were produced by immunising mice with Escherichia coli strain J5 (chemotype Rc). One of these bound to the deepest part of the core, i.e., Lipid A, and reacted with other heatkilled but not live gram-negative bacilli, including $E$. coli, Klebsiella pneumoniae and Pseudomonas aeruginosa. Eight other monoclonal antibodies, binding to the terminal glucose residue of Rc LPS, reacted with live cells of $E$. coli strains only. Thus, the $O$ antigen does not necessarily render the core inaccessible to antibody. However, despite binding to live bacteria, these monoclonal antibodies neither enhanced phagocytic killing, nor protected mice from dying from gram-negative infection or endotoxaemia. It is concluded that antibodies reacting with the most immunodominant parts of the $\mathrm{J} 5$ core are not protective.
\end{abstract}

\section{Introduction}

Antibodies reacting with the lipopolysaccharide (LPS) core have been shown to prevent death from gram-negative bacteraemia and endotoxaemia (Zinner and Peter, 1983; Telzak and Wolff, 1985). In these experiments, most investigators used polyclonal antisera to rough mutants of Escherichia coli strain J5, chemotype Rc or Salmonella minnesota strain R595, chemotype Re to immunise laboratory animals passively. In particular, Ziegler et al. (1982) demonstrated strikingly that human anti-J5 antiserum given to patients in severe shock reduced mortality significantly. It is difficult to prepare such an antiserum on a large scale; several investigators have, therefore, produced anti-core monoclonal antibodies from mouse cells (Dunn et al., 1983, 1985, 1986; Bogard et al., 1984; Mutharia et al., 1984; Nelles and Niswander, 1984; Young, 1984; Elkins and Metcalf, 1985; Kasai et al. 1985; Miner et al., 1986) or human cells (Raubitschek et al., 1985; Teng et al., 1985). The protection afforded by such monoclonal antibodies has been described by Dunn et al. (1983, 1985, 1986), Bogard et al. (1984), Young (1984) and Teng et al. (1985). Compared with some years ago (Peter et al., 1982), it is now

Received 25 Nov. 1986; revised version accepted 28 Aug. 1987. firmly established that anti-core antibodies protect, but several major questions have yet to be answered-are all antibodies to the core region protective, or, as a corollary, must a specific epitope be recognised in order to confer protection; do protective anti-core antibodies act primarily by promoting Fc-mediated opsonisation, so increasing phagocytosis and the killing of bacteria, or do they detoxify endotoxin by simple binding at or near its toxic groups? To answer these questions monoclonal antibodies reacting with different core epitopes must be produced and tested. This paper describes the production and characterisation of 12 such monoclonal antibodies.

\section{Materials and methods}

\section{Bacteria and growth conditions}

$E$. coli strain J5 and its parent strain $E$. coli serovar O111:B4 were provided by E. J. Ziegler, San Diego. E. coli strain ATCC 33985, serovar O125:B15 and Pseudomonas aeruginosa strain ATCC 27853 were bought from the American Type Culture Collection, Rockville, MD. $E$. coli strain $\mathrm{AD} 36 \mathrm{~K}^{-}$is a capsule-less mutant derived from $E$. coli strain O6K2H1 (Verweij-van Vught $e t$ al., 1983). S. minnesota strain R595 was obtained from G. Schmidt, Borstel, FRG, and Haemophilus influenzae 
(strain 760705) from A. J. W. van Alphen, Amsterdam. Strains of Klebsiella pneumoniae, Proteus mirabilis, $\boldsymbol{P}$. vulgaris, Staphylococcus epidermidis and Bacteroides fragilis strain BE1 were isolated from clinical specimens. The strain of $H$. influenzae was grown in Brain Heart Infusion Broth (Difco) containing NAD $1 \mu \mathrm{g} / \mathrm{ml}$ and haemin $10 \mu \mathrm{g} / \mathrm{ml}$ incubated in air plus $\mathrm{CO}_{2} 5 \%$. B. fragilis strain BE1 was grown anaerobically as described by Vel et al. (1985). The other strains were grown in Trypticase Soy Broth (BBL, Cockeysville, MD, USA).

\section{Vaccines and polyclonal antisera}

A vaccine of $E$. coli strain J5 was prepared as described by Appelmelk et al. (1985). Briefly, an overnight culture of strain $\mathrm{J} 5$ in trypticase soy broth was centrifuged, washed three times with $\mathrm{NaCl} 0.9 \% \mathrm{w} / \mathrm{v}$, and resuspended in $\mathrm{NaCl}$ to a concentration of $7 \times 10^{9} \mathrm{cfu} / \mathrm{ml}$; the suspension was heated in a boiling water bath for $2.5 \mathrm{~h}$. A vaccine of $E$. coli serovar O111:B4 containing $5 \times 10^{9}$ $\mathrm{cfu} / \mathrm{ml}$ was prepared similarly and used to immunise Swiss albino mice by injecting $0 \cdot 1 \mathrm{ml}$ intravenously (i.v.) on days 0,14 and 28 ; antiserum was obtained on day 42 by cardiac puncture.

\section{Rough strain lipopolysaccharides and Lipid A}

Lipid A from E. coli strain F515 was a gift from H. Brade, Borstel. The following lipopolysaccharides, and Lipid A from S. minnesota strain R595, were bought from List Biological Laboratories, Campbell, CA: LPS from $E$. coli strain $\mathrm{J} 5$, chemotype $\mathrm{Rc}$; and from $S$. minnesota strain R60, chemotype Ra; strain R345, chemotype $R_{2}$; strain R5, chemotype $R c$; strain $R 7$, chemotype $R_{1}$; and strain R595, chemotype Re. These LPS preparations from rough strains and Lipid A are referred to subsequently as core antigens.

\section{Production of monoclonal antibodies}

A BALB/c mouse was inoculated i.v. with $0.1 \mathrm{ml}$ of $\mathrm{J} 5$ vaccine on days $0,21,42$ and 45 . On day 48 , half of the spleen was fused with $8 \times 10^{7}$ myeloma cells of line no. X63-Ag8.653 as described by De Haan et al. (1985). Clones producing antibody were identified by enzymelinked immunosorbent assay (ELISA) (Appelmelk et al., 1985); twelve cell lines were stabilised by subcloning 2-4 times, and ascitic fluids produced with them in mice by injecting $5 \times 10^{6}$ hybridoma cells intraperitoneally (i.p.) and removing ascitic fluids after $2-3$ weeks.

\section{Reaction of anti-core monoclonal antibodies with Lipid $A$ and LPS from rough strains and determination of their immunoglobulin class and subclass}

The reaction of the anti-core monoclonal antibodies with core antigens was determined by ELISA (Appelmelk et al., 1985). In short, individual core antigens complexed to bovine serum albumin (BSA) were used to coat the solid phase. Serial dilutions of antibody-producing cellculture supernates or ascitic fluids, prepared in phosphate-buffered saline containing Tween $800.05 \% \mathrm{v} / \mathrm{v}$, $p \mathrm{H} 7.5$ (PBST), were added and incubated. Rabbit antimouse immunoglobulin (Ig) labelled with horseradish peroxidase (HRP) was used to detect reacting antibody. Plates coated with BSA alone served as controls. Optical densities (OD) were measured at $492 \mathrm{~nm}$ in a Dynatech MR 600 microtitration plate reader (Dynatech Laboratories, Billinghurst, Sussex).

The titre of each antibody was defined as the highest dilution producing an $\mathrm{OD}$ value $0 \cdot 1$ above the control value.

A similar ELISA was used to determine the Ig class and subclass with HRP-labelled goat anti-mouse IgG $(\mathrm{H}+\mathrm{L})$; anti-IgG1; anti-IgG2a; anti-IgG2b and antiIgG3; and rabbit anti-mouse IgM. These were obtained from Nordic, Tilburg, The Netherlands.

\section{Binding of anti-core monoclonal antibodies to heat- killed bacteria}

Bacteria grown to a concentration of $5 \times 10^{8} \mathrm{cfu} / \mathrm{ml}$ were washed three times in PBS, concentrated tenfold and boiled for $2.5 \mathrm{~h}$. Binding of antibody to bacteria thus treated was measured in a competitive assay in which $5 \times 10^{9}$ bacteria were mixed with an equal volume of ascitic fluid diluted 1 in 50000 in PBST, incubated for 16 $\mathrm{h}$ at $22^{\circ} \mathrm{C}$ and centrifuged. The antibody content of the supernatant fluids was titrated by ELISA in which the appropriate core antigen, i.e., either LPS from strain J5 or Lipid A was used to coat the plates. Diluted ascitic fluid, incubated overnight without bacteria, served as a control. When monoclonal antibody bound to bacteria, its titre fell. To ensure that binding was specific, two further controls were included : each monoclonal antibody was incubated in the conditions described above with gram-positive organisms ( $S$. epidermidis) before titration. All heat-killed bacteria were incubated with diluted Pen 7 ascitic fluid (De Haan et al., 1985). This monoclonal antibody binds to benzylpenicillin but not to LPS. In this case, non-specific binding was sought by titrating the supernatant fluids in an ELISA in which benzylpenicillin conjugated with transferrin was used to coat the solid phase (De Haan et al., 1985).

\section{Binding of anti-core monoclonal antibodies to live cells of E. coli serovars $0111: B 4$ and $0125: B 15$}

The method described above for heat-killed cells was modified as follows: to ensure maximum viability, an overnight bacterial culture was diluted 1 in 100 in fresh trypticase soy broth and grown at $37^{\circ} \mathrm{C}$ to the mid-log phase; the bacteria were washed and concentrated, and $5 \times 10^{9} \mathrm{cfu}$ were incubated with diluted ascitic fluid for 1 $h$ at $37^{\circ} \mathrm{C}$.

The binding of monoclonal antibodies, or polyclonal mouse antiserum to live $E$. coli cells was also investigated 
more directly by immunofluorescence: cells of $E$. coli serovar O111:B4 in the exponential phase were washed and suspended in PBST to $5 \times 10^{8} \mathrm{cfu} / \mathrm{ml}$, and incubated for $1 \mathrm{~h}$ at $37^{\circ} \mathrm{C}$ with an equal volume of ascitic pool diluted 1 in 10 in PBST, or with similarly diluted mouse antiserum to this strain. Cells were washed in PBST, and incubated with FITC-labelled porcine anti-immunoglobulin (Nordic), diluted 1 in 50 in PBST. After washing the cells in distilled water, they were air-dried on microscope slides and immersed in PBS-buffered glycerol. Fluorescence was examined with a Leitz Orthoplan microscope (Wetzlar, GDR) equipped with an HBO 200 lamp and a I2 filter block.

\section{Effect of anti-core monoclonal antibodies on the Limulus assay}

Lipid A from $S$. minnesota strain R595 complexed with BSA was used to activate Limulus amoebocyte lysate (Coatest, Kabi Vitrum, Sweden) in accordance with the procedure recommended by the manufacturers. A standard dose-response curve was first obtained before the ability of anti-core monoclonal antibodies to inhibit the assay was measured as follows: the Ig fraction of a pool of equal volumes of all ascitic fluids was separated by precipitation with $50 \%$ saturated ammonium sulphate and reconstituted to the original volume in PBS. Ten-fold dilutions, from 1 in 10 to 1 in $10^{6}$ were made; samples $(10 \mu \mathrm{l})$ of each dilution corresponding to amounts of undiluted Ig of $1-10^{-5} \mu \mathrm{l}$ were incubated with $50 \mathrm{pg}$ of Lipid A for $45 \mathrm{~min}$ at $37^{\circ} \mathrm{C}$; thereafter the effect of these mixtures on the standard Limulus assay was measured. Ig from Pen 7 ascitic fluid, prepared in the same way, served as a control.

\section{Effect of anti-core monoclonal antibodies on the killing of cells of $E$. coli in the mouse peritoneal cavity}

This was measured by the method of Galanos et al. (1971), modified as follows: cells of $E$. coli serovar O111:B4 in the exponential phase were washed, and resuspended in saline to a concentration of $5 \times 10^{5} \mathrm{cfu} /$ $\mathrm{ml}$. Equal volumes of the bacterial suspension and of each of the following antiserum preparations were mixed and incubated for $45 \mathrm{~min}$ at $37^{\circ} \mathrm{C}$ : a pool of all ascitic fluids containing equal volumes of anti-core antibodies; Pen 7 ascitic fluid; mouse polyclonal antiserum to $E$. coli serovar O111:B4 diluted 1 in 10. After incubation, 0.2 $\mathrm{ml}$ of each mixture was injected i.p. into twelve 10-weekold female Swiss albino mice. At zero time and at 30,60 and $90 \mathrm{~min}$ thereafter, three mice from each group were killed by spinal dislocation and the abdominal skin disinfected and removed. Bacteria were recovered from the peritoneal cavity by injecting $2 \mathrm{ml}$ of PBS into the peritoneal cavity, massaging the abdominal wall and withdrawing $1 \mathrm{ml}$ of fluid which was incubated for $5 \mathrm{~min}$ at $22^{\circ} \mathrm{C}$ with $1 \mathrm{ml}$ of lysis buffer (Zierdt, 1982) pH 7.5, consisting of $0.01 \mathrm{M} \mathrm{Na} \mathrm{NaPO}_{4}$, Tween $801 \% \mathrm{v} / \mathrm{v}$ and trypsin $0.025 \% \mathrm{w} / \mathrm{v}$. Immediately thereafter the fluid was spread on agar plates to determine the number of cfu present, with a spiral plating system (Spiral System Instruments, Inc., Md, USA). The results were analysed by Student's $t$ test.

\section{Effect of anti-core monoclonal antibodies in protecting mice against fatal bacteraemia caused by E. coli serovar $0111: B 4$}

A suspension of cells of $E$. coli serovar O111:B4 in the exponential phase was serially diluted in tenfold steps in PBS and added to a suspension in PBS of mucin (type II, Sigma, St Louis, MO, USA) and bovine haemoglobin (BBL, Cockeysville, MD, USA) (Marks et al., 1982). Samples $(0.5 \mathrm{ml})$ containing 50-50 $000 \mathrm{cfu}$ and mucin 6\% $\mathrm{w} / \mathrm{v}$, haemoglobin $1.6 \% \mathrm{w} / \mathrm{v}$ were injected i.p. into four groups of six mice each. Two batches of mucinhaemoglobin, differing in potency, were used. Test mice were inoculated i.p. with $0.3 \mathrm{ml}$ of pooled ascitic fluids $24 \mathrm{~h}$ before challenge. The LD50 was calculated by the method of Spearmann-Kärber (Finney, 1971) from the number of deaths recorded after 1 week and the significance of the results calculated by the $\chi^{2}$ test.

\section{Effect of anti-core monoclonal antibodies in protecting against fatal endotoxaemia}

The ability of anti-core monoclonal antibodies to prevent death from endotoxaemia was investigated with the actinomycin D-sensitised mouse model (Johns et al., 1983; Appelmelk et al., 1985). Groups of six mice were challenged i.p. with J5 LPS $(0 \cdot 1,1,10$ or $100 \mathrm{ng}$ per mouse) or lipid A (10,100 or $1000 \mathrm{ng}$ per mouse). A volume of $0.1 \mathrm{ml}$ was injected, consisting of endotoxin suspended in pyrogen-free PBS with $20 \mu \mathrm{g}$ of actinomycin D.

\section{Results}

\section{In-vitro characterisation of anti-core monoclonal antibodies}

Forty of the 720 wells into which the fusion mixture was distributed contained anti-core antibody. Table I shows the reaction of these with the following core antigens: LPS from $E$. coli strain J5 and S. minnesota strains R5 and R595, and Lipid A from $S$. minnesota strain R595. Thirteen of these cell lines were selected for further growth. One (line no. 13, producing IgG3 binding to LPS from strains J5 and R5) stopped producing antibody. The titres of antibody in ascitic fluids prepared with the remaining 12 lines, measured by ELISA against each of the core antigens, are shown in table II. 
Table I. Reaction with core antigens and the immunoglobulin subclass of 40 anti-core monoclonal antibodies

\begin{tabular}{|c|c|c|c|c|c|}
\hline \multirow{2}{*}{$\begin{array}{l}\text { Number of } \\
\text { monoclonal } \\
\text { antibodies }\end{array}$} & \multicolumn{4}{|c|}{ Reaction with core antigen } & \multirow{2}{*}{$\begin{array}{l}\text { Ig subclass } \\
\text { (number of } \\
\text { antibodies) }\end{array}$} \\
\hline & J5 LPS & R5 LPS & R595 LPS & R595 Lipid A & \\
\hline 36 & + & + & - & - & $\begin{array}{l}\text { IgG1 (1) } \\
\text { IgG2a (1) } \\
\operatorname{IgG3(34)}\end{array}$ \\
\hline $\begin{array}{l}2 \\
2\end{array}$ & $\begin{array}{l}+ \\
-\end{array}$ & - & - & $\bar{t}$ & $\begin{array}{l}\operatorname{lgG} 3(2) \\
\operatorname{IgG} 2 b(1)\end{array}$ \\
\hline
\end{tabular}

$+=$ binding; $-=$ no binding.

Table II. Titres measured by ELISA of 12 anti-core monoclonal antibodies

\begin{tabular}{|c|c|c|c|c|c|c|c|c|c|}
\hline \multirow[b]{2}{*}{$\begin{array}{l}\text { Cell line } \\
\text { no.* }\end{array}$} & \multicolumn{9}{|c|}{ Titre against $\dagger$} \\
\hline & $\begin{array}{r}\text { E. coli } \\
\text { Lipid A }\end{array}$ & $\begin{array}{c}\text { R595 } \\
\text { Lipid A }\end{array}$ & $\begin{array}{l}\mathrm{R} 595 \\
(\mathrm{Re})\end{array}$ & $\begin{array}{c}\mathbf{R 7} \\
\left(\mathbf{R d}_{1}\right)\end{array}$ & $\begin{array}{l}\text { E. coli } \\
\text { J5 (Rc) }\end{array}$ & $\begin{array}{c}\text { R5 } \\
\text { (Rc) }\end{array}$ & $\begin{array}{l}\mathrm{R} 345 \\
\left(\mathrm{Rb}_{2}\right)\end{array}$ & $\begin{array}{l}\mathrm{R} 60 \\
(\mathrm{Ra})\end{array}$ & $\begin{array}{c}\text { IgG sub- } \\
\text { class }\end{array}$ \\
\hline 1 & $10^{5}$ & $10^{6}$ & $<$ & $<$ & $<$ & $<$ & $<$ & $<$ & $2 \mathrm{~b}$ \\
\hline 6 & $10^{6}$ & $10^{6}$ & $<$ & $<$ & $<$ & $<$ & $<$ & $<$ & 3 \\
\hline 7 & $<$ & $<$ & $<$ & $<$ & $10^{6}$ & $<$ & $<$ & $<$ & 3 \\
\hline 10 & $<$ & $<$ & $<$ & $<$ & $10^{6}$ & $<$ & $<$ & $<$ & 3 \\
\hline 2 & $<$ & $<$ & $<$ & $<$ & $10^{6}$ & $10^{4}$ & $<$ & $<$ & 1 \\
\hline 4 & $<$ & $<$ & $<$ & $<$ & $10^{7}$ & $10^{6}$ & $<$ & $<$ & $2 a$ \\
\hline 5 & $<$ & $<$ & $<$ & $<$ & $10^{7}$ & $10^{6}$ & $<$ & $<$ & 1 \\
\hline $3,8,9,11$ & $<$ & $<$ & $<$ & $<$ & $10^{6}$ & $10^{6}$ & $<$ & $<$ & 3 \\
\hline 13 & $<$ & $<$ & $<$ & $<$ & $10^{5}$ & $10^{5}$ & $<$ & $<$ & 3 \\
\hline
\end{tabular}

* Line no. 12 lost production.

† Unless otherwise stated, the LPS core antigens used were isolated from $S$. minnesota rough strains.

$<=$ titre $<10^{3}$.

Binding of anti-core monoclonal antibodies to heatkilled bacteria and to live $E$. coli

The ability of antibody in ascitic fluid produced with cell line 3 (representative of antibody from all 12 cell lines) to bind to heat-killed bacteria is shown in fig. 1. The ELISA results formed two separate zones, the first representing binding to cells of the strains of $E$. coli (antibody from cell-line 3 bound to cells of the four strains of $E$. coli tested), and the second showing that this antibody did not bind to cells of the other gram-negative species tested. Readings given by antibody incubated without bacteria fell in the second zone. Antibody from the other cell lines was tested in the same manner, except those from cell lines 1 and 6 , which were titrated for their ability to bind to Lipid A after being incubated with bacteria. The results are shown in table III; this table also contains the results obtained in experiments with live cells of $E$. coli serovars O111:B4 and O125:B15. Despite repeated testing, antibody from cell lines 1,2 and 7 gave very inconsistent results; these have been omitted from table III. None of the 12 antibodies tested bound to $S$. epidermidis cells. Pen 7 antibody did not bind to any bacterial strain tested.

Live $E$. coli cells (serovar O111:B4) treated with homologous mouse antiserum exhibited a very bright fluorescence; in contrast, only a faint fluorescence was seen after treatment with the ascitic pool. Thus, in comparison with the polyclonal antiserum, the monoclonal antibodies bound very much less well to the bacterial surface.

\section{Effects of anti-core monoclonal antibodies on the Limulus assay}

A representative dose-response curve, with lipid A-BSA used for activation, is shown in fig. 2. No effect of anti-core antibodies on this assay was detected. 


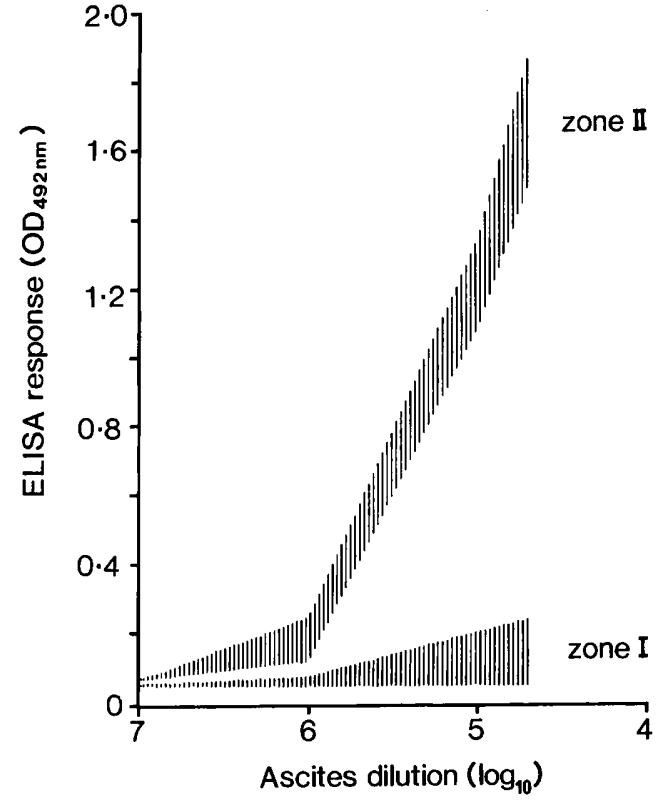

Fig. 1. Titration of antibody from cell line no. 3 against LPS from $E$. coli strain J5 after incubation with heat-killed bacteria. Zone $\mathrm{I}$ : response after incubation with $E$. coli strains $\mathrm{J} 5$, serovars O111:B4, O125:B15 and $36 \mathrm{~K}^{-}$. Zone II: response after incubation with Ps. aeruginosa, $S$. minnesota strain $\mathrm{R} 595, H$. influenzae, $K$. pneumoniae, $B$. fragilis, $P$. mirabilis, $P$. vulgaris and S. epidermidis.

\section{Influence of anti-core antibodies on the clearing of} live cells of $\mathrm{E}$. coli serovar O111:B4 from the mouse peritoneal cavity

The results of these experiments are shown in fig. 3. Treatment with anti-core monoclonal antibody did not result in significantly greater killing of $E$. coli after i.p. injection than in controls $(\mathrm{p}=0 \cdot 31)$. However, treatment with polyclonal mouse antiserum to $E$. coli serovar $\mathrm{O} 111$ :B4 did significantly enhance killing of bacteria, compared to treatment with anti-core antibodies $(\mathrm{p}<0.01)$ or with Pen 7 antibody $(\mathrm{p}<0.001)$

\section{Effect of monoclonal anti-core antibodies in preventing lethal gram-negative infection and endotoxaemia}

Monoclonal anti-core antibodies given to mice before challenge with live bacteria or endotoxin did not protect them (table IV).

\section{Discussion}

Antibodies to the core of LPS from $E$. coli or $S$. minnesota have been shown to prevent the lethal effects of gram-negative bacteraemia and endotoxaemia, but neither the target site of these antibodies

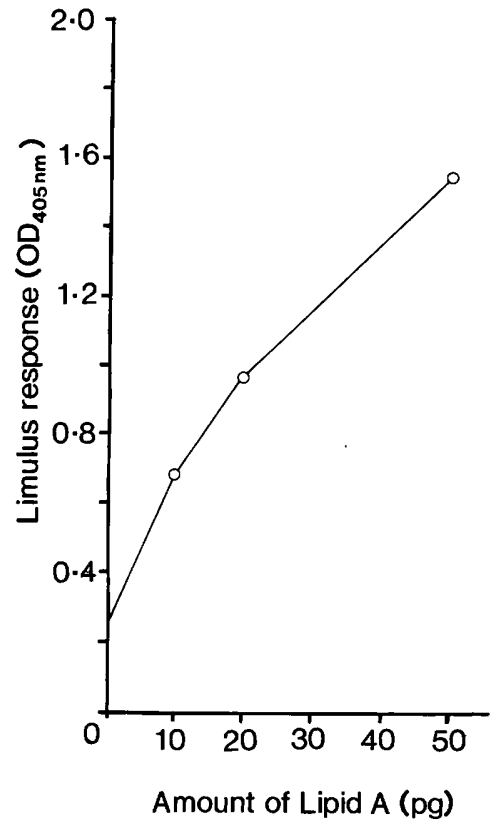

Fig. 2. Activation of Limulus lysate with Lipid A-BSA.

nor the way in which they protect is clear. A better understanding of the protective effect requires the characterisation of the binding pattern of a large number of monoclonal antibodies, recognising different epitopes.

Most $(75 \%)$ of the monoclonal antibodies produced in the present study were of the IgG3 subclass; few antibodies from other subclasses were present. Restriction of the antibody response to the

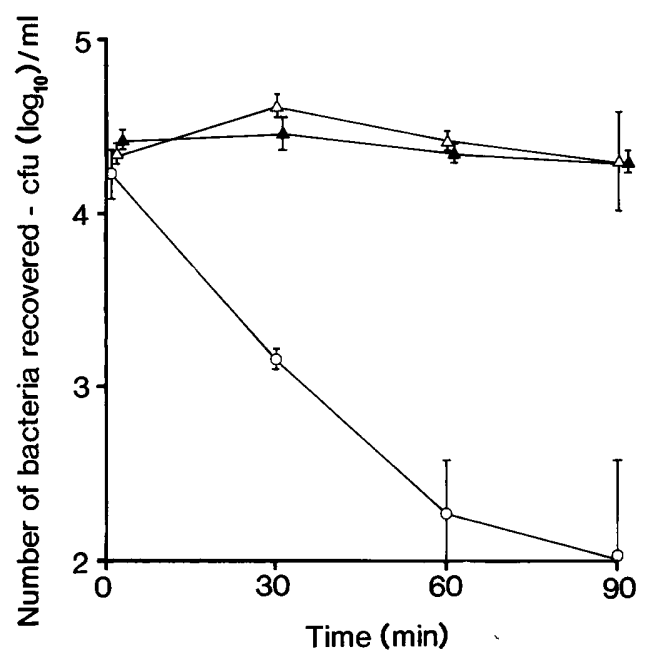

Fig. 3. Killing by mouse peritoneal cells of $E$. coli serovar O111:B4 after treatment with: Pen 7 antibody ( $\mathbf{\Delta})$, anti-core ascitic pool $(\triangle)$, or polyclonal mouse anti-E. coli O111:B4 antiserum $(O)$. Bars represent $95 \%$ confidence limits. 
Table III. Binding of anti-core monoclonal antibodies to heat-killed gramnegative bacteria and to live E. coli O111:B4 and O125:B15

\begin{tabular}{|c|c|c|c|c|}
\hline \multicolumn{4}{|c|}{ Binding to } & \multirow{3}{*}{$\begin{array}{c}\text { Live } E \text {. coli strains } \\
\\
\text { (O111:B4 and } \\
\text { O125:B15) }\end{array}$} \\
\hline \multirow[b]{2}{*}{$\begin{array}{l}\text { Cell line } \\
\text { no. }\end{array}$} & \multicolumn{3}{|c|}{ Heat-killed bacteria } & \\
\hline & E. coli J5 & $\begin{array}{l}\text { Other } E \text {. coli } \\
\text { strains* }\end{array}$ & $\begin{array}{c}\text { Non- } E \text {. coli } \\
\text { strains } \dagger\end{array}$ & \\
\hline 6 & + & + & + & - \\
\hline 10 & + & - & - & ND \\
\hline $\begin{array}{l}3,4,5,8 \\
9,11,13\end{array}$ & + & + & - & + \\
\hline $\begin{array}{l}+=\text { bindi } \\
\mathrm{ND}=\text { not } \\
{ }^{*} \text { E. coli } \mathrm{O} \\
\dagger \text { Ps. aeru } \\
\text { mirabilis, }\end{array}$ & $\begin{array}{l}=\text { no binc } \\
\text { ined. } \\
, \mathrm{O} 125: \mathrm{E} \\
\text { S. minn } \\
\text { ris. }\end{array}$ & $\begin{array}{l}\text { d AD } 36 \mathrm{~K}^{-} \\
\mathrm{R} 595, H .\end{array}$ & zae & iae, B. fragilis, \\
\hline
\end{tabular}

Table IV. The effect of anti-core monoclonal antibodies in protecting mice from fatal gram-negative infection and endotoxic shock

\begin{tabular}{cllc}
\hline Experiment no. & Treatment before challenge & Challenge & LD50 \\
\hline \multirow{2}{*}{ I } & anti-core ascitic pool & live bacteria & $123 \mathrm{cfu}$ NS \\
& none & live bacteria & $140 \mathrm{cfu}$ \\
II & Pen 7 ascitic fluid (control) & live bacteria & $1285 \mathrm{cfu}$ \\
& line 2 ascitic fluid & live bacteria & $2312 \mathrm{cfu} \mathrm{NS}$ \\
& line 4 ascitic fluid & live bacteria & $724 \mathrm{cfu} \mathrm{NS}^{\mathrm{a}}$ \\
III & line 6 ascitic* fluid & Lipid A-BSA & $220 \mathrm{ng} \mathrm{NS}$ \\
& none & Lipid A-BSA & $330 \mathrm{ng}$ \\
IV & anti-core ascitic pool & J5 LPS-BSA & $1 \mathrm{ng} \mathrm{NS}$ \\
& none & J5 LPS-BSA & $0.5 \mathrm{ng}$ \\
V & Pen 7 ascitic fluid (control) & J5 LPS-BSA & $0.7 \mathrm{ng}$ \\
& line 2 ascitic fluid & J5 LPS-BSA & $3.1 \mathrm{ng} \mathrm{NS}$ \\
& line 3 ascitic fluid & J5 LPS-BSA & $0.7 \mathrm{ng} \mathrm{NS}$ \\
& line 4 ascitic fluid & J5 LPS-BSA & $0.3 \mathrm{ng} \mathrm{NS}$ \\
& line 5 ascitic fluid & J5 LPS-BSA & $2.2 \mathrm{ng} \mathrm{NS}$ \\
& line 7 ascitic fluid & J5 LPS-BSA & $3.2 \mathrm{ng} \mathrm{NS}$ \\
& & & \\
\hline
\end{tabular}

$\mathrm{NS}=$ not significant from untreated controls; $\mathrm{NS}^{\mathrm{a}}=\mathrm{LD} 50$ compared to Pen 7 controls. * Antibody from cell line 6 binds to Lipid A.

IgG3 subclass has already been described by Perlmutter et al. (1978). From binding assay data (table II), the binding site of most of the antibodies examined in the present study could be localised precisely: antibody from cell lines $2,3,4,5,8,9,11$ and 13 bound to LPS from strains J5 and R5 (both Rc chemotypes), but not to LPS from $S$. minnesota strains R595 (chemotype $\mathrm{Re}$ ), $\mathbf{R} 7$ (chemotype $\mathrm{Rd}_{1}$ ), $R 345$ (chemotype $R b_{2}$ ) or R60 (chemotype $R a$ ), nor to Lipid A. From a review of the molecular structures of these core antigens (Galanos et al., 1984) it can be stated that all these antibodies bind to the terminal glucose residue present in the Rc structure, i.e., this glucose residue is an immunodominant group. Immunodominance of the terminal, non-reducing sugar is common when rough strains are used as immunogens (Galanos et al., 1984). Considering the ratio of their titres to LPS from strains $\mathrm{J} 5$ and $\mathrm{R} 5$, the antibodies can be divided into three groups, each recognising a different epitope on the terminal glucose residue: (i) a group characterised by a ratio of $1: 1$, exemplified by antibody from cell lines $3,8,9,11$ and 13 ; (ii) a group with a ratio of $10: 1$, including 
antibody from cell lines 4 and 5; and (iii) a group with a ratio of $100: 1$, containing antibody from cell line 2. Furthermore, although the prime target of antibody from cell lines 2,4 and 5 is the terminal glucose residue, binding of these three antibodies is influenced by molecular groups in the cores of $E$. coli and $S$. minnesota LPS, most likely from the nearby heptose regions, which are not identical. Antibody from cell lines 7 and 10 did not bind to LPS from rough Salmonella strains and must, therefore, bind to an epitope unique to $E$. coli. Antibody from cell lines 1 and 6 did bind to free Lipid A from $E$. coli and $S$. minnesota, but not when covalently linked (i.e., there was no binding to LPS from strains of chemotype $\mathrm{Re}$ ) and in so doing behaved like polyclonal antibodies to Lipid A (Galanos et al., 1984). Several investigators have produced monoclonal antibodies to Lipid A with similar binding characteristics (Elkins and Metcalf, 1985; Kasai et al., 1985), but monoclonal antibodies reacting with both free and covalently bound Lipid A have also been described (Bogard et al., 1984; Young, 1984; Dunn et al., 1985, 1986; Kasai et al., 1985; Raubitschek et al., 1985; Teng et al., 1985).

The monoclonal antibody from cell line 6 which bound to Lipid A reacted with a panel of gramnegative strains, including the anaerobe $B$. fragilis (table III); evidently the site it recognises is present in all these species. In contrast, the three epitopes recognised on the terminal glucose of chemotype $\mathrm{Rc}$ were present in $E$. coli strains only.

Antibody from cell line 6 did not bind to live bacteria, and so also behaved like polyclonal antisera to Lipid A (Mullan et al., 1974). Antibody from cell lines $3,4,5,8,9,11$ and 13 reacted with live cells of $E$. coli serovars O111:B4 and O125:B15. Thus, at least some epitopes of the LPS core can react with antibody on the surface of intact, smooth bacteria. In contrast, Gigliotti and Shenep (1985) were unable to demonstrate such binding to live bacteria. Differences both in the kind of anti-core monoclonal antibodies used to study binding and in experimental conditions may explain these conflicting results.

The monoclonal antibodies examined in the present study did not inhibit the Limulus assay. It has been calculated that the lack of inhibition was probably not due to a lack of competing antibody, but to the antibodies' intrinsic inability to inhibit.

Live $E$. coli cells, incubated with anti-core antiserum, were not better cleared by mouse peritoneal cells than were controls incubated with Pen 7 antibody although anti-core antibodies bound to live bacteria. In contrast, polyclonal antibody to $E$. coli serovar 0111:B4 significantly enhanced bacterial killing. With immunofluorescence techniques it was found, in the latter case, that much more antibody was bound to the bacterial surface than in the case of bacteria treated with anti-core antibody. We hold this minimal binding responsible for the lack of effect of anti-core monoclonal antibodies in this assay.

The anti-core monoclonal antibodies examined in the present study did not protect mice against lethal endotoxaemia, nor against experimental gram-negative sepsis. Protective monoclonal antibodies described so far belong to the IgM class (Young, 1984; Teng et al., 1985), the IgGl subclass (Bogard et al., 1984; Dunn et al., 1985, 1986) and the IgG class (subclass not specified) (Dunn et al., 1983).

It is possible that the absence of IgM antibodies from the set tested in the present study explains their failure to protect, but it is more likely, however, that they fail to protect because they do not recognise the right epitope, search for which has so far met with limited success. Because Lipid A is the toxic part of LPS, antibodies to Lipid A are, theoretically, most likely to be those that protect. However, rabbit antibodies to Lipid A that bind solely to free Lipid A do not protect except in very special experimental conditions (Rietschel and Galanos, 1977), in contrast to antibodies to $S$. minnesota R595 (Mullan et al., 1974; Bruins et al., 1977). The absence of free Lipid A from the surface of intact bacteria has been put forward to explain this lack of protection (Mullan et al., 1974), but this conflicts with the present finding that monoclonal antibody to Lipid A (from cell line 6) did not protect mice challenged with free Lipid A (table IV). It can be calculated that although the amount of antibody injected was sufficient to bind to at least $99.5 \%$ of the Lipid A present in the challenge dose, clearly, antibody binding did not block the toxic groups.

It is noteworthy that two protective anti-core monoclonal antibodies described recently (Bogard et al., 1984; Teng et al., 1985; Dunn et al., 1986) bound to both free and covalently linked Lipid A, i.e., to an epitope on Lipid $\mathrm{A}$ other than that recognised by non-protective polyclonal antibody to Lipid A or by antibody from cell line 6 .

To investigate this further, monoclonal antibodies to the ketodesoxyoctonate region of LPS have been prepared and are being studied.

This work was supported in part by the Praeventiefonds. We thank E. J. Ziegler (San Diego) for giving advice and A. J. van Winkelhoff and $E$. Claassen for critically reading the manuscript. Ms E. Seinen provided excellent secretarial assistance. The artwork was skilfully done by J. G. Meijer and J. M. Verbeek. 


\section{REFERENCES}

Appelmelk B J, Verweij-van Vught A M J J, MacLaren D M, Thijs L G 1985 An enzyme-linked immunosorbent assay (ELISA) for the measurement of antibodies to different parts of the Gram-negative lipopolysaccharide core region. Journal of Immunological Methods 82: 199-207.

Bogard W C, Abernethy K, Dunn D L, Kung P C 1984 Murine monoclonal antibodies against gram-negative bacterial core-glycolipid: criteria for cross-genera reactivity. Federation Proceedings 43: 1682 abstract 1553.

Bruins S C, Stumacher R, Johns M A, McCabe W R 1977 Immunization with $\mathbf{R}$ mutants of Salmonella minnesota III. Comparison of the protective effect of immunization with Lipid A and the Re mutant. Infection and Immunity 17: 1620.

De Haan P, De Jonge A J R, Verbrugge T, Boorsma D M 1985 Three epitope-specific monoclonal antibodies against the hapten penicillin. International Archives of Allergy and Applied Immunology 76: 42-46.

Dunn D L, Mach P A, Cerra F B 1983 Monoclonal antibodies protect against lethal effects of Gram-negative bacterial sepsis. Surgical Forum 44: 142-143.

Dunn D L, Bogard W C, Cerra F B 1985 Efficacy of type-specific and cross-reactive murine monoclonal antibodies directed against endotoxin during experimental sepsis. Surgery 98 : $283-290$.

Dunn D L, Ewald D C, Chandan N, Cerra F B 1986 Immunotherapy of gram-negative bacterial sepsis. A single murine monoclonal antibody provides cross-genera protection. Archives of Surgery 121 : 58-62.

Elkins K, Metcalf E S 1985 Binding activity of a murine antiLipid A monoclonal antibody. Infection and Immunity 48: $597-600$

Finney D J 1971 Statistical method in biological assay, 2nd edn. Griffin, London, p 524.

Galanos C, Luderitz O, Westphal O 1971 Preparation and properties of antisera against the Lipid A component of bacterial lipopolysaccharides. European Journal of Biochemistry 24: 116-122.

Galanos C et al. 1984 Immunogenic properties of Lipid A. Reviews of Infectious Diseases 6: 546-552.

Gigliotti F, Shenep J L 1985 Failure of monoclonal antibodies to core glycolipid to bind intact smooth strains of Escherichia coli. Journal of Infectious Diseases 151 : 1005-1011.

Johns M, Skehill A, McCabe W R 1983 Immunization with rough mutants of Salmonella minnesota. IV. Protection by antisera to $O$ and rough antigens against endotoxin. Journal of Infectious Diseases 147: 57-67.

Kasai $\mathrm{N}$ et al. 1985 In-vitro antigenic reactivity of synthetic Lipid $\mathrm{A}$ analogues as determined by monoclonal and conventional antibodies. Biochemical and Biophysical Research Communications 128: 607-612.

Marks M I, Ziegler E J, Douglas H, Corbeil L B, Braude A I 1982 Induction of immunity against lethal Haemophilus influenzae type b infection by Escherichia coli core lipopolysaccharide. Journal of Clinical Investigation 69: 742-749.
Miner K M et al. 1986 Characterization of murine monoclonal antibodies to Echerichia coli J5. Infection and Immunity 52: 56-62.

Mullan N A, Newsome P M, Cunnington P G, Palmer G H, Wilson M E 1974 Protection against gram-negative infections with antiserum to Lipid A from Salmonella minnesota R595. Infection and Immunity 10: 1195-1201.

Mutharia L M, Crockford G, Bogard W C, Hancock R E W 1984 Monoclonal antibodies specific for Escherichia coli J5 lipopolysaccharide: cross-reaction with other gram-negative bacterial species. Infection and Immunity 45: 631-636.

Nelles M J, Niswander C A 1984 Mouse monoclonal antibodies reactive with $\mathrm{J} 5$ lipopolysaccharide exhibit extensive serological cross-reactivity with a variety of gram-negative bacteria. Infection and Immunity 46: 677-681.

Perlmutter R M, Hansburg D, Briles D E, Nicolotti R A, Davie J M 1978 Subclass restriction of murine anti-carbohydrate antibodies. Journal of Immunology 121 : 566-572.

Peter G, Chernow M, Keating M H, Ryff J C, Zinner S H 1982 Limited protective effect of rough mutant antisera in murine Escherichia coli bacteremia. Infection 10: 228-232.

Raubitschek A A, Pollack M, Larrick J W 1985 Preparation of human monoclonal antibodies (mAbs) that react with the conserved core region of endotoxin (LPS) Clinical Research 33: $416 \mathrm{~A}$.

Rietschel E T, Galanos C 1977 Lipid antiserum-mediated protection against lipopolysaccharide-and Lipid A-induced fever and skin necrosis. Infection and Immunity 15: 34-49.

Telzak E E, Wolff S M 1985 Immunotherapy and immunoprophylaxis of Gram-negative rod bacteremia. In: Root R K, Sande M A (eds) Septic shock. Churchill Livingstone, New York, pp 257-276.

Teng N N H et al. 1985 Protection against gram-negative bacteremia and endotoxemia with human monoclonal IgM antibodies. Proceedings of the National Academy of Sciences of the USA 82: 1790-1794.

Vel W A C, Namavar F, Verweij-van Vught A M J J, Pubben A N B, MacLaren D M 1985 Killing of Escherichia coli by human polymorphonuclear leucocytes in the presence of Bacteroides fragilis. Journal of Clinical Pathology 38: 86-91.

Verweij-van Vught A M J J, Van den Bosch J F, Namavar F, Sparrius M, MacLaren D M $1983 \mathrm{~K}$ antigens of Escherichia coli and virulence in urinary tract infection: studies in a mouse model. Journal of Medical Microbiology 16: 147-155.

Young L S 1984 Monoclonal antibodies: technology and application to gram-negative infections. Infection 12: 303308.

Ziegler E J et al. 1982 Treatment of gram-negative bacteremia and shock with human antiserum to a mutant of Escherichia coli. New England Journal of Medicine 307: 1225-1230.

Zierdt C H 1982 Blood-lysing solution nontoxic to pathogenic bacteria. Journal of Clinical Microbiology 15: 172-174.

Zinner S H, Peter G 1983 The potential role of cell wall core glycolipids in the immunoprophylaxis and immunotherapy of gram-negative rod bacteriaemia. In: Easmon C S F, Jeljaszewicz J (eds) Medical microbiology, vol. 2, Immunization against bacterial disease. Academic Press, London, pp 71-85. 